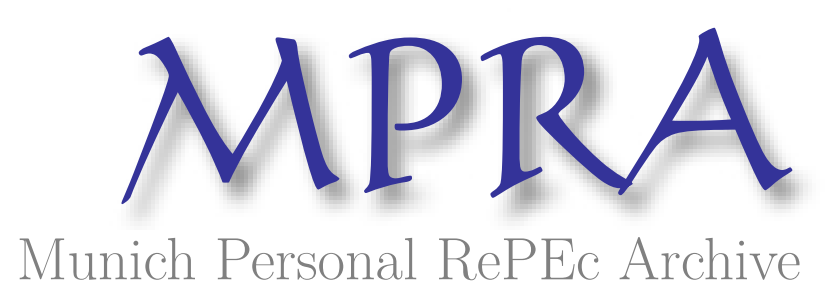

\title{
Naxal problem in India an economic analysis
}

\author{
Pradhan, Raj Kishor
}

6 March 2013

Online at https://mpra.ub.uni-muenchen.de/54178/

MPRA Paper No. 54178, posted 07 Mar 2014 19:49 UTC 


\section{NAXAL PROBLEM IN INDIA: AN ECONOMIC ANALYSIS \\ Raj Kishor Pradhan}

\section{INTRODUCTION-}

India, having one of the fastest growing economies in the world, and being the most populous democratic country, has great potential to become a future superpower. However, in this increasingly globalised environment, India faces several threats to its security. The Naxalites has been identified as the biggest internal security threat to India by none other than the Prime Minister Manmohan Singh. The complex and structural causes of the problem support this proposition. The Naxal movement also presents the greatest overall threat to India in the future, as it highlights various underlying weaknesses of India's governance, political institutions and socio-economic structure.

Naxal, naxalite are generic terms used to refer various militant communist groups operating in different parts of India under different organization structure. Naxalism is the biggest threat because it affects several areas including the economy, security and foreign affairs, its 
citizens and rule of law. Because of the multi-dimensional aspect of the Naxal problem, a three-pronged approach should be taken in dealing with the threat. It calls for a balance between military forces, social and economic development, as well as dialogue between all parties. . Therefore it is realised by the different strata's of the society to understand the root cause of the Naxal problem and its solution.

The objective of the paper is to present different methods of solution and particularly give emphasis on economic solution. The plan of the paper is divided into three parts. In first part we will analyse the brief history of naxal problem. In second part we will discuss the various factors responsible for Naxalism. Thirdly we discuss the possible solution of the problem.

The Maoist movement may have started off on purely altruistic terms but has metamorphosed over the years into an ugly monster indecipherable from its original avatar as encapsulated in this incisive description ( $R$ S N Singh, Associate Editor IDR. Maoist Threat and Politics. India Defence Review.Vol 25.1. Jan-March 2010):.Naxal, Naxalite and Naksalvadi are generic terms used to refer to various militant communist groups operating in different parts of india. In the eastern states of the mainland India (Chhatisgarh,Jharkhand,West Bengal and Odisha), they are usually known as , or refer to themselves as Maoists while in southern states like Andhra Pradesh they are known under other titles. The term Naxalites comes from Naxalbari, a small village in West Bengal in 1967. The Naxals are considered far-left radical communists, supportive of Maoist political sentiment and ideology. Their origin can be traced to the split in 1967 of the Communist Party of India(Marxist) ,leading to the formation of the Communist Party of India (Marxist-Leninist). Initially the movement had its centre in West 
Bengal. In later years, it spread into less developed area of rural southern and eastern India, such as Chhattisgarh, Odisha and Andhra Pradesh through the activities of underground groups like the CPI(M).For the past 10 years, it has grown mostly displaced tribal and natives who are fighting against exploitation from major Indian corporations and local officials whom they believe to be corrupt. Now they resort to mean of violence to achieve their goal. Therefore Naxalites or red violence is one of the growing menaces in India. NowFor last forty years Naxalism has been spread from an obscure village of Naxalbari in West Bengal to rest of the country. Now even our Prime Minister has also admitted that naxal or Maoist is great internal threat to our country. The so called "Red Corridor" of India has hugely attracted domestic and international attention. In last few years their bloody game has not only put common people on spot but also the govt. The 'Red terror' spots have begun to pop up in India's capital and northern States' forest and hilly areas too. It seems that the Maoists are interested in enlarging their area of influence outside the jungles of the 'Red Corridor' that runs from the Nepal border down to Andhra Pradesh. Lately, they have begun targeting India's seat of power-New Delhi—and many other cities by setting up urban bases with the aim to penetrate and influence policy makers, judiciary, media, civil liberty, human rights, cultural, Dalit, women and youth organisations. So far, the urban units are not indulging in violence. But who knows when they may start firing guns. Their fearless and bold attack on our paramilitary forces, police forces, common citizens, political leaders and also on government properties took a huge toll in term of property and human lives. Human lives are precious. The preceding five years was a watershed period in the fight against Naxalism for it was marked by an exponential and dangerous growth in this scourge. In 2004, Naxalites were confined to 156 of India's 602 districts. By 2008, Naxalites had expanded their reach into 180 districts or roughly one third of the nation's territory. 
The same period saw Naxalites-related incidents assume alarming proportions, both in terms of frequency and intensity. In 2003 there were 1,597 incidents. By 2009, this number had shot up to 2,239 -- an increase of nearly 40 percent. Additionally the number of casualties suffered by security forces reached an all time high of 317 in 2009 compared to 217 Naxal casualties. And for three years running the annual death toll of security personnel has consistently exceeded the corresponding figures for Naxalites deaths -- not a reassuring statistics.

There are various factors responsible for Naxalism. These are the political, social, historical and economical factor. It should be bear in the mind that naxal problems are not merely a media propaganda .Definitely it is a serious problem, which going to hurt our ambition of next economic superpower.

The main factor is India's long neglect to develop the tribal areas which has created large pockets of alienation against the government and these pockets have become the spawning ground of Maoist terrorism. The governments concerned have to take note of the genuine grievances of the tribal's and deal with them in a sympathetic manner. There has to be a system for a prompt enquiry into all allegations of excess. Naxal problem has its origin in deeply rooted negligence of tribal and landless people by the Government. After sixty four years of independence the govt is unable to provide the basic necessity to the bottom half of the population. Naxalism never flourish in northern part of India but obscure central and eastern part of India. In this part of country basically the states of West Bengal, Bihar, Odisha, Jharkhand, Chhattisgarh and Andhra Pradesh etc are basically hugely tribal dominated area. Historically these tribal people are more freedom minded, they deeply attached to their land, forest. They neither interfere others life, nor they prefer the interference of others. But the development of the economy definitely affects the interest of the common man. Here the lack of basic governance is main problem. In these areas there is lack of 
communication, basic health care facility and education, banking facility etc.Therefore the government machinery are virtually failed. Government officials are scared to be posted here. Therefore the decentralisation of the local government has not been fulfilled here. Therefore these peoples are alienated from the mainstream of the nation. This vacuum has been fulfilled by the Maoists in these areas. Therefore the Maoist terrorism cannot be effectively countered without modernising and strengthening our rural policing and the rural presence of the intelligence agencies. The tribal areas, which have not yet been affected by the Maoist virus, have to be developed on a crash basis in order to prevent the spread of the virus to them.

There are various factors responsible for rise of Naxalism. Important among them are political and economical factors. But here we focused on economic perspectives of Naxalism. Besides the political factors, economic factors have also acted as a catalyst in giving momentum to the movement. Economically, the problem of poverty and economic inequality can be identified as vital in accelerating the pace of movement. The absolute numbers of the poor have fallen over the decades. According to the planning commission report now the people below poverty line is $22 \%$ of the population (in the year 2009-10, NSSO Report); the statistics being averages do not capture the intensity of distress in certain pockets despite the high growth in recent years. To be poor is one thing and to seem condemned to one's fate quite another. Rising incomes in the post-reform India have created a rapidly growing aspirational class but these have also contributed to an army of socio-economic orphans who have been rejected by all mainstream political parties. These downtrodden people comprises of tribal, dalits, landless poor are the majority of the population. They are depriving of the basic necessary of the human life. The fruit of economic growths has not reached to them In addition, a contractor-politician nexus controls the wealth of the forests and pushes tribal's to 
the margins. A repressive state apparatus, represented by the police and the black laws they use to their advantage, helps keep this exploitative system going.

The situation has further worsened by the opening up of the Indian economy to trade and investment; the entry of the multinational companies in Odisha and Chhattisgarh poses a threat to the livelihoods of tribal and their way of life. These MNCs are eyeing on the vast natural resources like minerals, forest products etc.The SEZ and demand of raw materials for the industrial development has put pressure on forest and mining areas. But the then govt law regarding mining etc has underestimated the interests of the tribal.Largescale displacement has been taken place due to establishment of large-scale mineral based industries and hydel dams. Thus economic exploitation of the tribal, a problem that is unattended by the political system, creates a fertile soul for the Naxals to play an important role.

The study of various factors thus indicates that Naxalism is the outcome of not just one factor but a number of various factors. One can really have a proper grip of the problem by focusing on the psychology of the individuals who are a part of the movement. The psychological factors synthesise well the above mentioned factors - political and economic — and facilitate a clear understanding of the roots of the movement.

The impact of Naxalism on economic growth and development is very severe. For sound development of the economy it requires a peaceful environment. But Naxalism is now creating a war like situation in certain states. They are operating a parallel rules in that states. Unfortunately these areas are increasing day by day. For example the Bastar region of Chhatisgarh, undivided Koraput district of Odisha is the hotbed of Maoist activities. In these areas the rule of law is absent. Therefore economic activities remain standstill. 
Therefore Government has understood the gravity of the situation. It has formed various committees to deal with the naxal problem.In May 2006, the Planning Commission appointed an expert committee headed by D. Bandopadhyay, a retired IAS officer instrumental in dealing with the Naxalites in West Bengal in the 1970s. The expert committee has underscored the social, political, economic and cultural discrimination faced by the SCs/STs across the country as a key factor in drawing large number of discontented people towards the Naxalites. The committee established the lack of empowerment of local communities as the main reason for the spread of the Naxal movement. Choosing its words carefully, the report states that "We have two worlds of education, two worlds of health, two worlds of transport and two worlds of housing..."

The expert committee delved deep into the new conflict zones of India, i.e. the mines and mineral rich areas, steel zones, as well as the SEZs. The report holds the faulty system of land acquisition and a non-existent R\&R Policy largely responsible for the support enjoyed by the Naxalites. On the other hand, the committee makes a forceful plea for a policy and legal framework to enable small and marginal farmers to lease-in land with secure rights while landless poor occupying government land should not be treated as encroachers.

For the first time in the history of the Naxal movement, a government appointed committee has put the blame on the State for the growth of the movement. Providing statistics of 125 districts from the Naxal-affected States, the committee finds out that the state bureaucracy has pitiably failed in delivering good governance in these areas. The report recommends rigorous training for the police force, not only on humane tactics of controlling rural violence but also on the constitutional obligation of the State for the protection of fundamental rights. 
Making a departure from the usual government position, the expert committee concludes that development paradigm pursued since independence has aggravated the prevailing discontent among the marginalized sections of society. Citing democratic principles, the report also argues for the right to protest and discovers that unrest is often the only thing that actually puts pressure on the government to make things work and for the government to live up to its own promises.

Dealing with Naxalism needs a holistic approach with development initiatives as an integral part of the security approach.

\section{Solutions}

The complexity of the causes of the Naxalite problem as well as its implications both for internal and external security reflect a solution that is multi-dimensional and calls for a synergy between the central governments and the states. In order to comprehensively dissolve the Naxalite threat, the government has to address its root causes. Socio-economic alienation and the dissatisfaction with the widening economic and political inequality will not be solved by military force alone, which seems to be the main instrument employed by the government. The problem calls for a three-pronged solution: social and economic development, multi-lateral dialogue and military force.

Socio

economic

development

As the Naxalites are fuelled by discontent from the marginalised and the poor, a larger percentage of the national budget must be allocated to addressing the needs of these regions. More of the national expenditure needs to be focused on developing these poorer regions through initiatives regarding health, education, social welfare and rural and urban development. Government service delivery should be improved in these tribal areas. Both state 
and government must ensure that things such as statutory minimum wages, access to land and water sources initiatives are implemented. In coming up with strategies for national economic growth, the government must always bear in mind the possible effects of fast growth for all socio-economic groups in a country as large and diverse as India. If the social needs of these marginalised people are addressed, there will be no discontent to fuel the Naxalite's movements.

\section{Governance}

The growing Naxalite insurgency also reflects a flaw in the federal structure. Because law and order is seen as a state responsibility, the central government is unable to be implementing a coherent national strategy to address the threat. Ganguly notes that "in the absence of a near complete breakdown of public order or without the express request of the afflicted state, the central government cannot... [Intervene]." The government has the overall responsibility of mobilising development, but it cannot do so without the support of the states. The central government and the states need to cooperate together to solve the internal security threats and coordinate the implementation of this multi-dimensional approach. Both organisations must complement and support each other's initiatives and strategies. But the present economic growth models are advocating of that type of economic growth which is not sustainable. For example this part of our country is mineral rich. Therefore multinational companies are interested to exploit these areas at any cost. But at the cost of lower strata of the people, these people are tribal people and landless farmer. These are the person whom has to be displaced but not gained anything in return. Therefore large scale dissatisfaction is arising. Governance is totally absent there. Recent lethal attack of Naxalites on Congress leaders in Chhattisgarh are pointer of lack of Government coordination there. Although govt policy is good, if implementation is nil then serious problems arise. This is the main reason for rising of Maoist insurgency in these areas. Counter terrorism activity like 
'Operation green hunt' is never a solution for this problem. Then what is the solution? Actually there is no quick fix solution of this problem. The need of the hour is good governance. The public also do their bit to solve this problem. We cannot criticise the establishment for each and every problem. Here the role of public or civil society is very important. Government is making every possible effort by making all possible policies and instruments. But to implement all the policies and to create awareness among the public, the role of civil society is also very important.

References:

1. Sarabjit Kaur-'Towards Understanding Naxalism’ Mainstream-Vol XLVIII, No-12, March 13, 2010

2. Aletha Cherian- 'Naxalism- The Biggest Security Threat to India' 2010

3. Vivek Gumaste-'The Naxal Problem: 'Failure of Political leadership'- Rediff.com-27-04-2010

4. 'The Naxalite Problem of India'- Competition Master 2009

5. Naxalites- wikipedia 
